\title{
Morphological relationships among fronds of giant kelp Macrocystis pyrifera off La Jolla, California
}

\author{
George A. Jackson, David E. James* \& Wheeler J. North* \\ Institute of Marine Resource, Scripps Institution of Oceanography, University of California, San Diego, La Jolla, \\ California 92093, USA
}

\begin{abstract}
Giant kelp Macrocystis pyrifera is the dominant macrophyte along much of the California coast. Each plant is composed of several fronds, each of which can have more than 100 blades. We have developed equations which describe relationships between size and distance which account for variations in frond size and blade node number The most successful descriptions involve the separation of within-frond patterns from between-frond patterns. One useful within-frond description is the relationship between the area of blade relative to the largest blade on its frond (e.g. a fractional area of 0.1 ) as a function of its relative position on the frond (e.g. the blade's node position is 0.1 of the total number of nodes from the apex). A useful between-frond description is the relationship between the area of the largest blade on a frond and the frond size. The 2 types of descriptions used together form a compact description of frond morphology that accounts for most of the variability in blade size and position for a range of frond sizes. Similar relationships hold for the distributions of frond lengths within a kelp plant. The morphological relationships are expressed used power series that were fit to the data. The existence of power series relationships describing kelp morphology can be used for modelling studies of such factors as the light field around a plant.
\end{abstract}

\section{INTRODUCTION}

Giant kelp Macrocystis pyrifera is the dominant seaweed along much of the California coast. Recently, several workers have attempted to identify morphological, development, and physiological patterns among Macrocystis fronds (Gerard 1976, Kain 1982, Lobban 1978a, b, North 1971a, 1972, Wheeler 1978). These studies furnish preliminary evidence that patterns do indeed exist within the bewildering variation that baffled earlier algologists.

North (1971a) described the morphology of Macrocystis pyrifera fronds in a larger work on the plant's systematics, life history, morphology, and ecology. As part of a study of growth of the plants, Kain (1982) described the detailed morphology of $M$. pyrifera specimens from both New Zealand and San Diego, California, using 3 to 5 fronds from each of 3 sites in New Zealand and 1 site in California. Because she was primarily interested in frond growth and because most

- Present address: Keck Laboratory, California Institute of Technology, Pasadena, California 91125, USA new tissue growth occurs near the apex, her analyses emphasized the region within 1 to $2 \mathrm{~m}$ of the apex.

Our study provides a more intensive examination of Macrocystis pyrifera morphology using more fronds than have been previously used. We start by examining the weight/area properties of an individual lamina. We then examine the distribution of the area of a lamina as a function of its position on a frond, with this position being determined as a node number or a distance from the apex. We proceed to examine the relationship between node number and distance from the apex. Having studied the distribution of tissue internal to a frond, we examine the relationships among frond properties including total frond length, total number of nodes, total lamina area on a frond, and total frond mass. One result of this work is a set of regression-determined curves describing locations and areas of blades for entire fronds. We show the value of these relationships with examples.

We shall use the terminology of Lobban (1978a) and North (1971a) to describe Macrocystis pyrifera plants. A typical plant has between 2 and 100 vinelike fronds attached to a basal holdfast. Frond lengths vary from 1 
to $2 \mathrm{~cm}$ initials recently formed from basal meristems to more than $40 \mathrm{~m}$, long enough to reach the surface and extend horizontally. Each frond is composed of an approximately $1 / 2 \mathrm{~cm}$ thick, rope-like stipe alternately subtending leaflike blades. Blades consist of flat laminae attached basally to gas-filled pneumatocysts which in turn attach to the stipes by pedicels. A growing frond constantly forms new blades and new stipe tissue distally from the base at the apical meristem. Because new stipe tissue continues to grow after formation, the apical meristem is propelled upward by the continued growth of tissue behind it. The location of a blade can be expressed as either an actual distance or the number of nodes that it is displaced from either end of the frond.

\section{METHODS}

Macrocystis pyrifera fronds were collected during summer 1958 and again in 1961. The 1958 collections were made to determine frond size distributions in individual plants. The 1961 studies examined fronds in detail, investigating distributions of weight and blade area along entire frond lengths.

The 1958 investigations were conducted by collecting entire plants from various locations in the La Jolla kelp bed. Only the healthiest-appearing plants were chosen for study. Plants were returned to the laboratory where fronds were disentangled and their lengths measured the same day as collection.

Fronds used in the 1961 analyses were collected from 2 to 4 yr old plants (as judged from their holdfast sizes) lying along a permanent $100 \mathrm{~m}$ transect line ca 3 $\mathrm{km}$ offshore from Bird Rock, La Jolla, depth $20 \mathrm{~m}$, $117^{\circ} 18.9^{\prime} \mathrm{W}, 32^{\circ} 48.8^{\prime} \mathrm{N}$. This was the only healthy stand of Macrocystis pyrifera existing in the La Jolla kelp bed at the time. Fronds representing a range of lengths (Fig. 1) were collected on the basis of freedom from encrustations and blade loss and on the presence

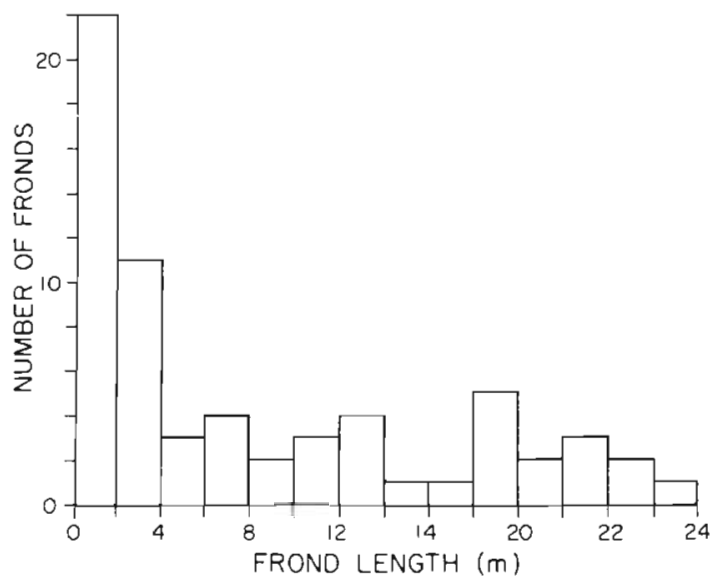

Fig. 1 Length distribution of fronds used in this study of either an apical or a terminal blade. Measurements included lamina area and weight at every node, distance from the holdfast of every 5th node, and wet weight of total stipe material, including all pneumatocysts (separated from the laminae). For a smaller set of fronds, stipe and pneumatocyst tissue were separated into 5 node segments and weighed. Measurement of lamina area has been described in North (1971b).

Lamina data for sporophyll tissues and apical meristems have been excluded from the ensuing computer analyses. Lamina/node positions have been recalculated to count from the apical meristem rather than the basal meristem. The within-frond data consist of measurements from 64 fronds and include areas and weights for 3151 laminae, length values for 652 and weight values for 326 five-node segments. Several of the figures in this paper show only a fraction of the total number of points used in regression calculations to avoid obliterating salient features of the figures with too many points. All available data, however, were used for the statistical tests and curve fitting.

The geometric mean regression (GM) of Ricker (1973) was used to fit straight lines to data and to estimate confidence limits of the slope for lamina area vs weight calculations in a manner similar to that of Kain (1982). Polynomial curves were fitted to the data using the least-squares minimizing subroutine RLFOR (IMSL, Houston, Texas) run on a Digital Equipment Corporation VAX $11 / 780$ computer. The order of the polynomial used was chosen to be the minimum that fit important features of the data. In most cases these were the same order as obtained from successive application of Student's t-test to the uncertainty of the coefficient of the highest power in the polynomial (Elias \& Causton 1976).

Because the fronds were not selected at random and the data are not normally distributed (Fig. 1), it is mathematically difficult to assign a statistical 'significance' to the regression relationships used to describe kelp morphology (e.g. Draper \& Smith 1966). We cite the percentage of the variance explained by a regression as a way to compare results from different mathematical data transformations but generally refrain from making significance tests.

\section{RESULTS}

\section{Blade relationships}

\section{Lamina density}

The slope of a GM line fit to the log fresh weight-log area data yielded $1.02 \pm 0.0099$ for the slope and the $95 \%$ confidence limits (Fig. 2). This value is statisti- 


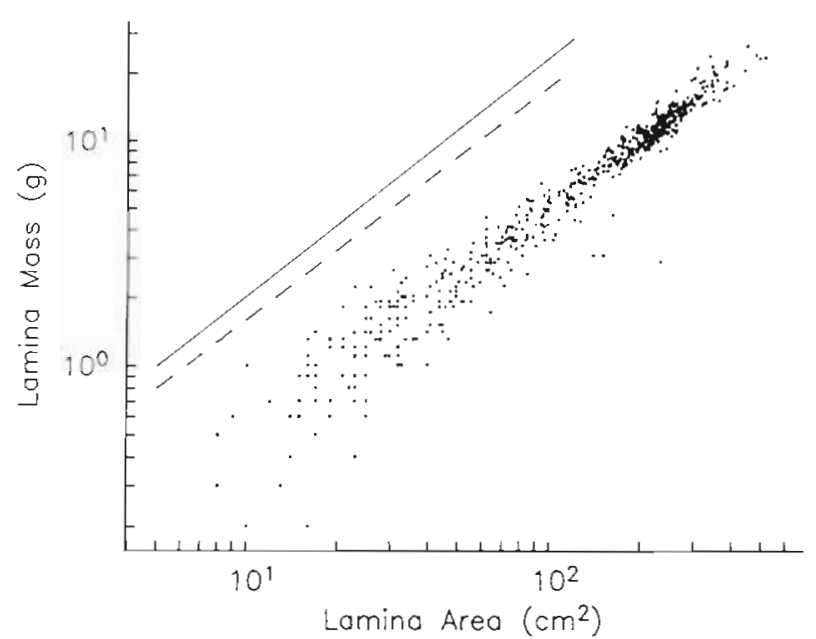

Fig. 2. Lamina weight as a function of lamina area. Solid line shows the slope of 1.02 determined from the GM regression on the log-transformed data. Dashed line shows the slope for a linear relationship between the 2 variables. Only $1 / 5$ of all points used to determine the GM relationship are shown

cally different from 1.0 at the 0.05 level (Student's ttest) but the absolute difference is small. If a $10 \mathrm{~cm}^{2}$ lamina weighs $0.5 \mathrm{~g}$, the $\log$ - $\log$ result implies that a $100 \mathrm{~cm}^{2}$ lamina should weigh $5.24 \mathrm{~g}$. A linear relationship with a constant density that was the same as the above would imply a $100 \mathrm{~cm}^{2}$ lamina weighing $5 \mathrm{~g}$. The difference between the linear and non-linear versions of the $100 \mathrm{~cm}^{2}$ lamina is less than $5 \%$.

A different way of relating weight and area is to study the distribution of lamina density (fresh weight/ area) as a function of node number. There was considerable variation of lamina density but mean lamina density at any node was fairly constant (Fig. 3). Average lamina density was $0.045 \mathrm{~g} \mathrm{~cm}^{-2}$. For the 5 to 10 nodes nearest the apex, where laminae were still growing rapidly, the lamina density was almost $0.040 \mathrm{~g}$ $\mathrm{cm}^{-2}$.

Lamina area distribution as a function of node number

When data from all fronds were lumped together, lamina area was a highly variable function of node position (Fig. 4). A 2nd-order polynomial fit to the data explained only $28 \%$ of the variance (Table 1 ). Blades near the base were never as large as blades farther away, no matter how large the frond (Fig. 5). Maximum area was about $75 \mathrm{~cm}^{2}$ for the 10th blade from the base, about $200 \mathrm{~cm}^{2}$ for the 20 th blade, and about $300 \mathrm{~cm}^{2}$ for the 30 th blade. The largest blade for a frond of 80 or more blades was typically 300 to $400 \mathrm{~cm}^{2}$ (Fig. 4). Lamina area varied as a function of position relative to the base as well as relative to the apex. As a result, laminae reach their largest size somewhere near the middle of a frond. Our data show that the area of the

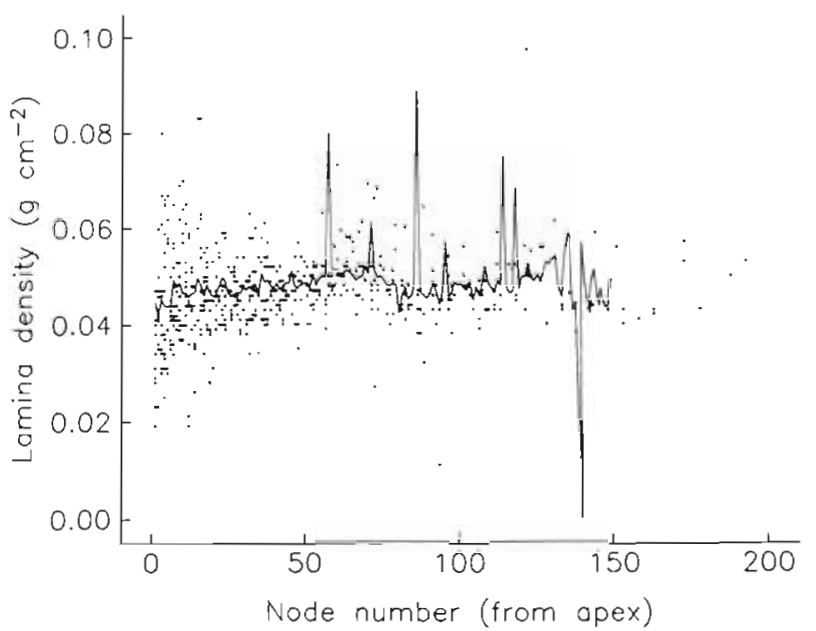

Fig. 3. Lamina density $\left(\mathrm{g} \mathrm{cm}^{-2}\right)$ as function of node number from apex. Solid line represents average density for all fronds at the different nodes, determined from 64 fronds. Variablity increases with higher node number because the number of fronds with the appropriate number of nodes on a frond decreases with higher node number. One-fifth of all points used are shown

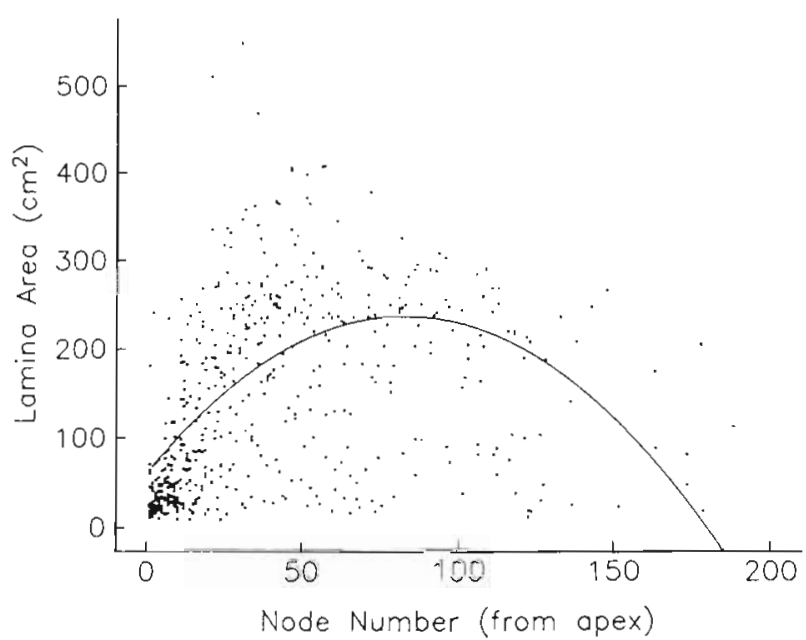

Fig. 4. Individual lamina area as a function of node number from apex. Line represents least squares fit of a 2 nd-order equation to the data (Table 1). One-fifth of all points used are shown

maximum size lamina increased with increasing number of nodes (Fig. 6). When the individual lamina areas on each frond were normalized by dividing each by the area of the largest lamina and the node numbers were normalized by dividing by the number of nodes on the frond, the curves of lamina area vs node number for different fronds roughly coincided (Fig. 7). A 4thorder polynomial fit to the normalized data explained $58 \%$ of the sample variance.

Much of the unexplained variance is caused by laminae with differing amounts of missing tissue. A technique for averaging out this within-frond variability is to sum (or integrate) lamina areas along a frond 
Table 1. Relationship between blade area and its position. Distance and node number measured from apex

\begin{tabular}{|c|c|c|c|c|}
\hline Fig. & $\mathrm{X}$ & $Y$ & Equation & $\begin{array}{c}\text { Variance } \\
\text { explained } \\
(\%)\end{array}$ \\
\hline 4 & Node no. & $\begin{array}{l}\text { Individual } \\
\text { lamina area }\left(\mathrm{cm}^{2}\right)\end{array}$ & $Y=60.0+4.2 X-0.025 X^{2}$ & 27.9 \\
\hline 7 & $\begin{array}{l}\text { Fractional } \\
\text { node no. }\end{array}$ & $\begin{array}{l}\text { Fraction of } \\
\text { largest lamina }\end{array}$ & $Y=0.039+2.8 X+0.048 X^{2}-7.3 X^{3}+4.7 X^{4}$ & 58.4 \\
\hline 8 & Node no. & $\begin{array}{l}\text { Accumulating } \\
\text { area }\left(\mathrm{cm}^{2}\right)\end{array}$ & $Y=-200.0+45.0 X+3.8 X^{2}-0.033 X^{3}+8.1 \times 10^{-5} X^{4}$ & 86.8 \\
\hline 9 & $\begin{array}{l}\text { Fractional } \\
\text { node no. }\end{array}$ & $\begin{array}{l}\text { Fractional } \\
\text { accumulating } \\
\text { area }\end{array}$ & $Y=0.012-0.19 X+4.7 X^{2}-5.0 X^{3}+1.4 X^{4}$ & 97.7 \\
\hline- & $\begin{array}{l}\text { Distance } \\
(\mathrm{cm})\end{array}$ & $\begin{array}{l}\text { Individual } \\
\text { area }\left(\mathrm{cm}^{2}\right)\end{array}$ & $Y=8.3+1.1 X-1.7 \times 10^{-3} X^{2}+9.5 \times 10^{-7} X^{3}$ & 30.2 \\
\hline- & $\begin{array}{l}\text { Fractional } \\
\text { distance }\end{array}$ & $\begin{array}{l}\text { Fraction of } \\
\text { largest lamina }\end{array}$ & $Y=0.036+7.4 X-24.0 X^{2}+28.0 X^{3}-12.0 X^{4}$ & 46.5 \\
\hline - & $\begin{array}{l}\text { Distance } \\
(\mathrm{cm})\end{array}$ & $\begin{array}{l}\text { Accumulating } \\
\text { area }\left(\mathrm{cm}^{2}\right)\end{array}$ & $Y=-1000.0+23.0 X-5.3 \times 10^{-3} X^{2}$ & 73.8 \\
\hline- & $\begin{array}{l}\text { Fractional } \\
\text { distance }\end{array}$ & $\begin{array}{l}\text { Fractional } \\
\text { accumulating } \\
\text { area }\end{array}$ & $Y=-0.08+3.3 X-4.1 X^{2}+1.9 X^{3}$ & 84.5 \\
\hline
\end{tabular}

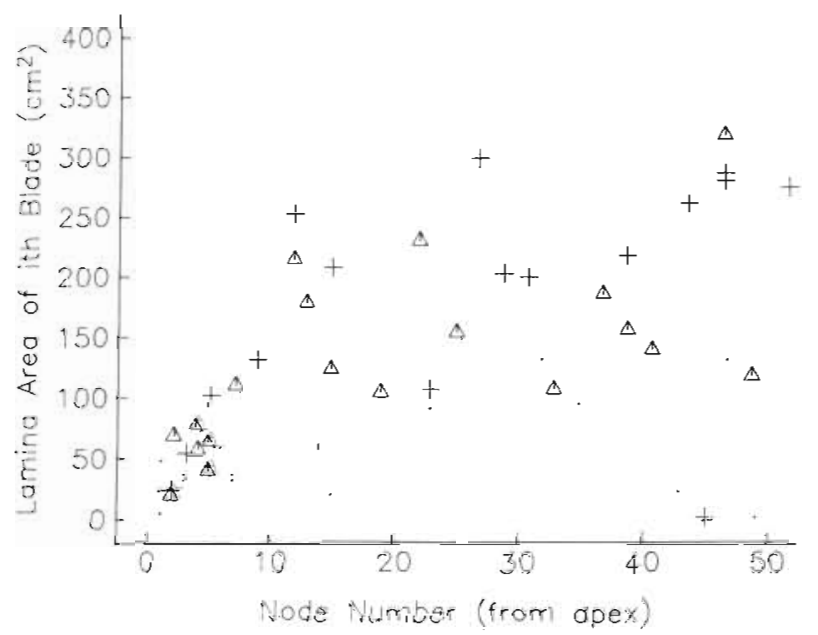

Fig. 5. Lamina area of blades at given positions from basal meristem as a function of their distance from apical meristem. The distance of a blade from the apex is an analog for its age. Comparing the area of all blades located 10 nodes from the basal meristem as a function of their apical position is a way of examining the effect of age on the area of a blade at a given location. Data for blades 10 nodes from the base (.), 20 nodes from the base $(\Delta)$, and 30 nodes from the base $(+)$

and express the running sum as a function of position (Fig. 8). A 4 th-order fit to these data explained $87 \%$ of the sample variance. Most of the remaining unexplained variance was caused by the effects of frond size. Using the normalization technique (dividing the area summed to a node by the total frond area and dividing the node number by the total number of

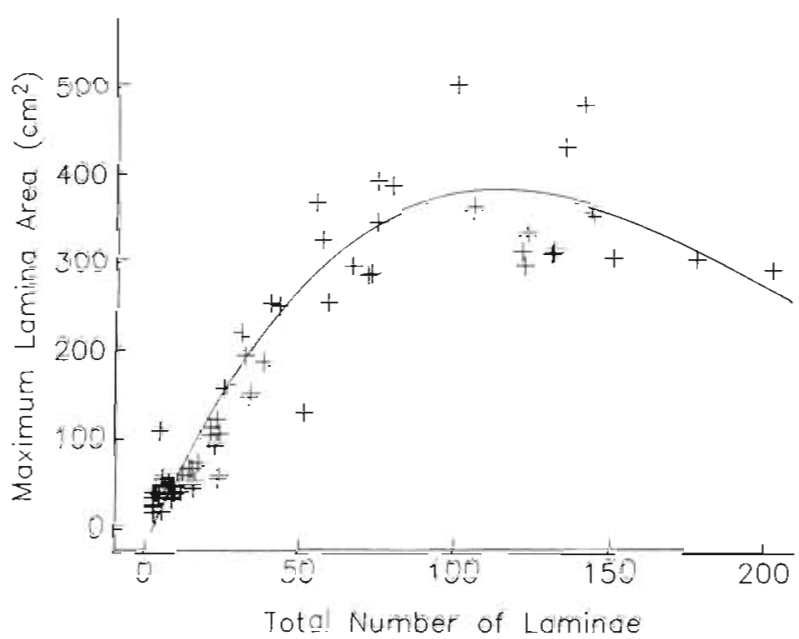

Fig. 6. Maximum lamina area on a frond as a function of total number of laminae on frond. Line shown is for a 3rd-order power series fitted to the data (Table 1)

nodes) increased the explained variance to $97.7 \%$ (Fig. 9).

Lamina area distribution as a function of distance from apex

Summed lamina area was also related to distance from the apex (Table 1). Transforming the data to fraction total area vs fraction total length (a procedure similar to that used to relate lamina area to node number) increased the variance explained to $84.5 \%$ 


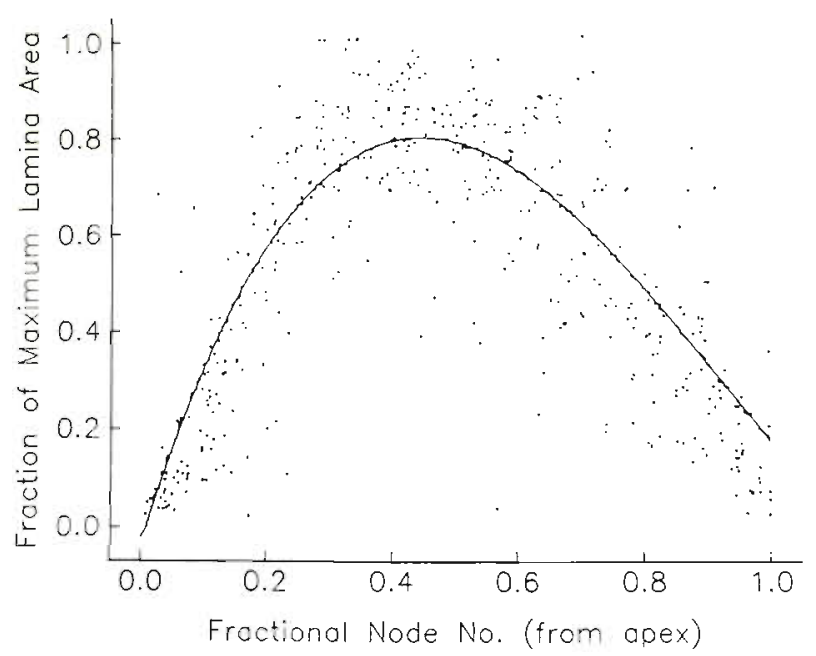

Fig. 7. Normalized lamina area as a function of normalized node number from apex. Normalized lamina area calculated by dividing lamina area at a node by area of the largest lamina on its frond; normalized node number calculated by dividing the node number of a lamina by the total number of laminae on its frond. Solid line represents least squares fit of a 3rd-order equation to the data (Table 1). One-fifth of the total points used are plotted

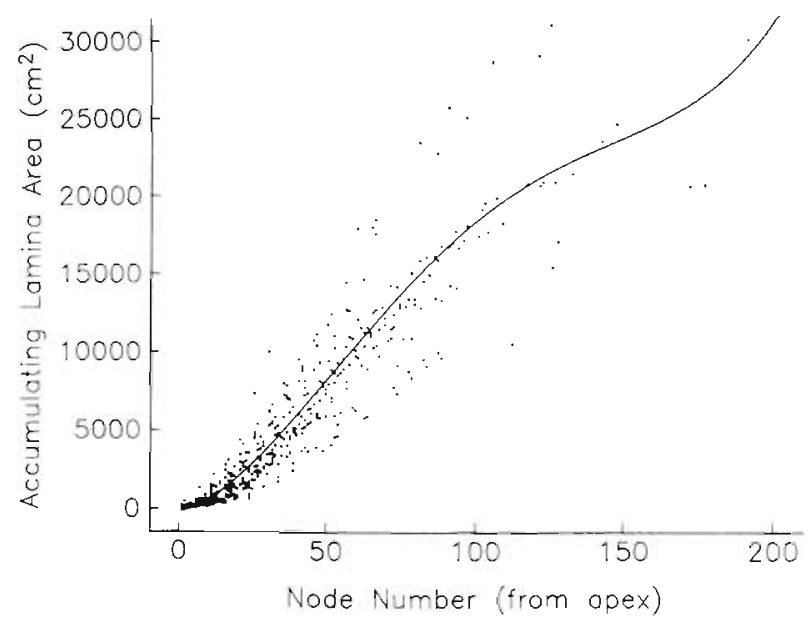

Fig. 8. Accumulating area as a function of node number. Accumulating area at a node is total lamina area between the node and the apex. Solid line shown is a 4 th-order fit to the data (Table 1). One-fifth of the total points used are plotted

(Table 1), less than the $97.7 \%$ explained by the node number treatment. Variance was thus more successfully explained by expressing lamina area as a function of node number than of distance.

Relationship between node number and distance from the apex

The distance to a given node varied among fronds (Fig. 10). When the integrated lengths were normalized by the overall frond length, a curve explained more of the

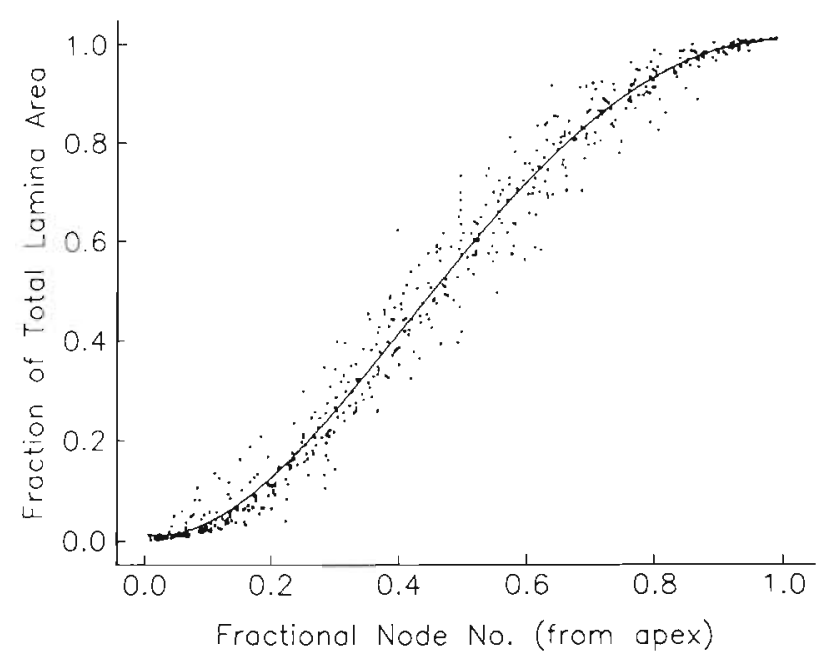

Fig. 9. Normalized accumulating area as a function of the normalized node number from the apex. Accumulating area at a node is total area between node and apex. It is normalized by dividing the accumulating area to a node by the total lamina area on the frond. Node numbers are normalized by dividing node number by total number of nodes on its frond. Solid line represents least squares fit to a 4 th-order equation (Table 1). One-fifth of the total points used are plotted

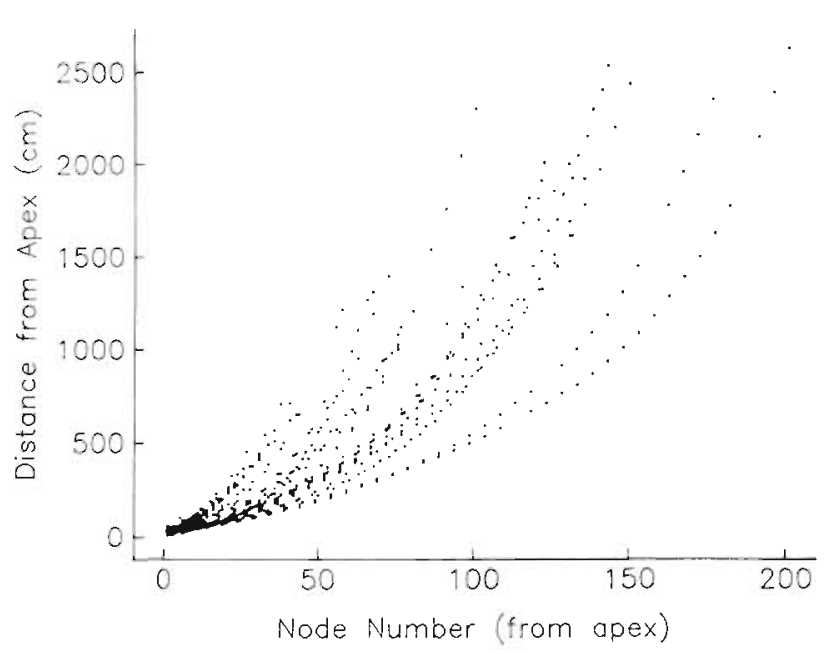

Fig. 10. Cumulative distance from apex as a function of node number. Every 5th node was measured

variance then explained by the un-normalized curve (Fig. 11, Table 2).

\section{Whole frond relationships}

Although the relation between node number and distance from the apex was quite variable (Fig. 10, Table 2), the total number of nodes on a frond was closely related to frond length (Fig. 12). Total frond weight and total stipe weight (frond weight less total lamina weight) were similarly related to overall length 


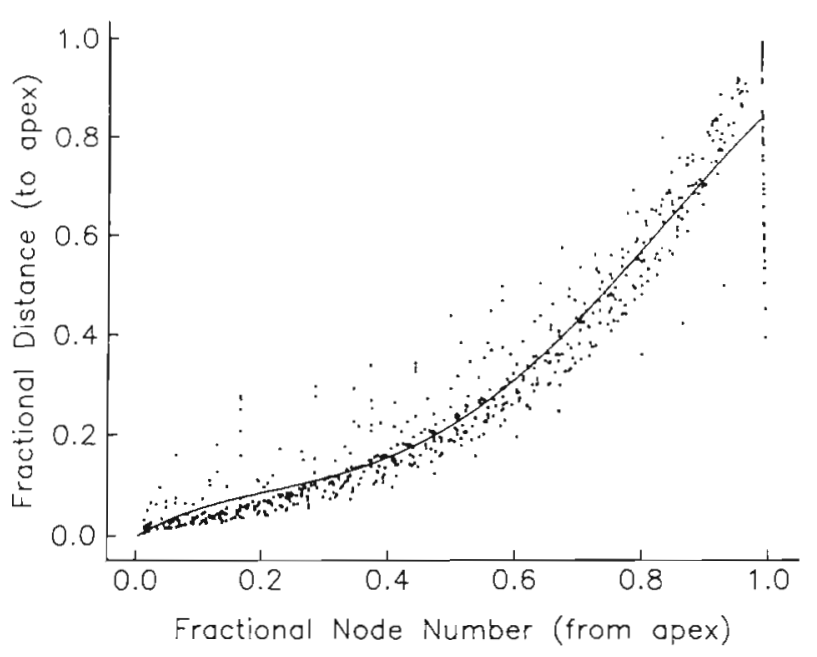

Fig. 11. Normalized distance from apex as function of normalized node number. Solid line is a 4 th-order fit to the data (Table 2). Distance measurements were only made for every 5 th node on a frond

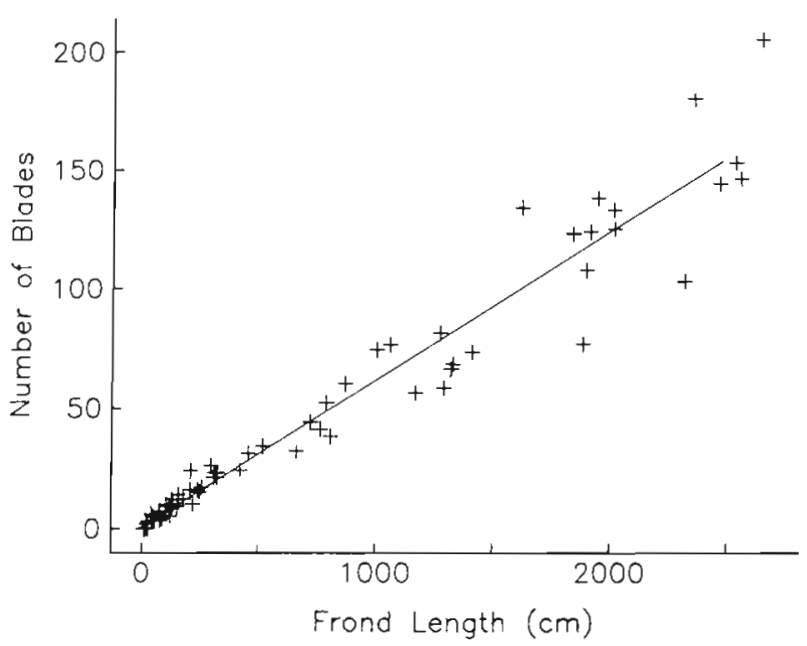

Fig. 12. Total number of nodes as a function of total frond length. Solid line represents least squares fit to a 1st-order equation (Table 3)

(Fig. 13). Total lamina area was highly related to both overall length and total node number (Table 3 ). The size of the maximum lamina on a frond was related to either total nodes (Fig. 6) or overall length (Table 3).

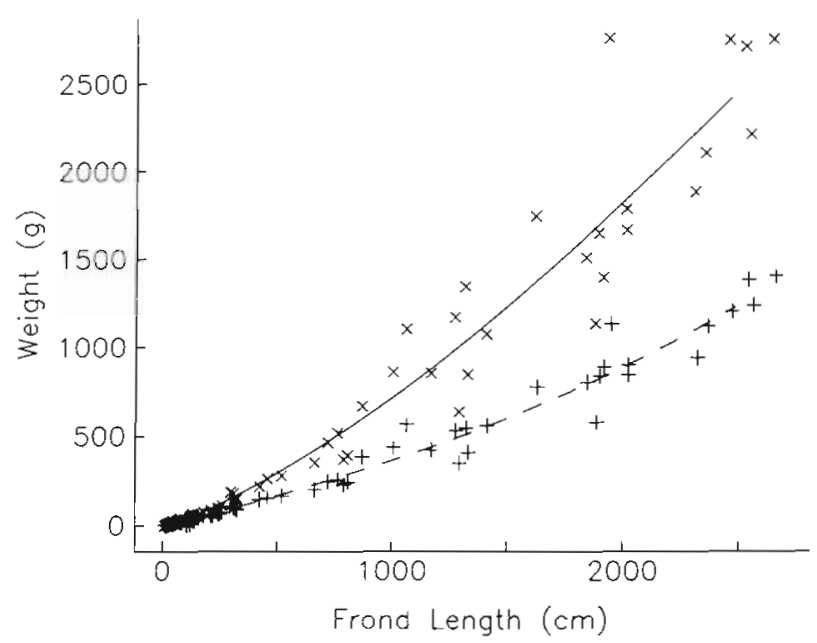

Fig. 13. Fresh weight as a function of total frond length. $\times=$ frond fresh weight, consisting of all tissue above the basal meristem, including sporophylls, laminae, and stipe; solid line represents least squares fit to a 3rd-order equation (Table $3) .+=$ total stipe weight, including weight of pneumatocysts; dashed line represents least squares fit to a 3rd-order equation (Table 3)

By checking for the presence of incomplete blades on a frond and substituting estimates of the maximal size of the missing blade, it is possible to estimate what the total biomass of a frond would have been if no matter had been lost. Our estimates were that frond biomasses would have averaged about $15 \%$ larger had there been no loss of tissue (Fig. 14).

\section{Distribution of fronds on a plant}

Frond length distributions within a plant were quite variable (Table 4). Normalization of frond length and frond number increased the variance that polynomial explained (Table 4). The maximum frond length was more related to water depth than to number of stipes in a plant (Table 4).

\section{DISCUSSION}

Kain (1982) used a GM line fit on log-transformed lamina weight-area data to show that weight and area

Table 2. Relationship between node number and distance

\begin{tabular}{|lllll}
\hline Fig. $\mathrm{X}$ & $\mathrm{Y}$ & Equation & $\begin{array}{c}\text { Variance } \\
\text { explained } \\
(\%)\end{array}$ \\
\hline 10 & Node no. & $\begin{array}{l}\text { Distance to } \\
\text { apex (cm) }\end{array}$ & $\mathrm{Y}=26.0+4.0 \mathrm{X}+0.089 \mathrm{X}^{2}-2.8 \times 10^{-4} \mathrm{X}^{3}$ & 81.3 \\
11 & $\begin{array}{l}\text { Fractional } \\
\text { node no. }\end{array}$ & $\begin{array}{l}\text { Fractional } \\
\text { distance }\end{array}$ & $\mathrm{Y}=-0.0046+0.77 \mathrm{X}-2.5 \mathrm{X}^{2}+4.9 \mathrm{X}^{3}-2.3 \mathrm{X}^{4}$ & 92.5 \\
\hline
\end{tabular}


Table 3. Relationships among different measures of frond size

\begin{tabular}{|c|c|c|c|c|}
\hline Fig. & $\mathrm{x}$ & Y & Equation & $\begin{array}{c}\text { Variance } \\
\text { explained } \\
(\%)\end{array}$ \\
\hline 12 & $\begin{array}{l}\text { Frond } \\
\text { length }(\mathrm{cm})\end{array}$ & $\begin{array}{l}\text { Total number } \\
\text { of blades }\end{array}$ & $Y=0.42+0.061 X$ & 94.6 \\
\hline 13 & $\begin{array}{l}\text { Frond } \\
\text { length }(\mathrm{cm})\end{array}$ & $\begin{array}{l}\text { Frond } \\
\text { weight }(g)\end{array}$ & $Y=-20.0+0.51 X+2.5 \times 10^{-4} X^{2}-2.7 \times 10^{-8} X^{3}$ & 94.6 \\
\hline 13 & $\begin{array}{l}\text { Frond } \\
\text { length }(\mathrm{cm})\end{array}$ & $\begin{array}{l}\text { Stipe } \\
\text { weight }(g)\end{array}$ & $Y=-11.0+0.34 X+1.8 \times 10^{-5} X^{2}+1.7 \times 10^{-8} X^{3}$ & 97.5 \\
\hline- & $\begin{array}{l}\text { Frond } \\
\text { length }(\mathrm{cm})\end{array}$ & $\begin{array}{l}\text { Total lamina } \\
\text { area }\left(\mathrm{cm}^{2}\right)\end{array}$ & $Y=-450.0+5.1 X+3.8 \times 10^{-3} X^{2}-7.3 \times 10^{-7} X^{3}$ & 90.2 \\
\hline- & $\begin{array}{l}\text { Frond } \\
\text { length }(\mathrm{cm})\end{array}$ & $\begin{array}{l}\text { Area of largest } \\
\text { lamina }\left(\mathrm{cm}^{2}\right)\end{array}$ & $Y=-0.45+0.38 X-9.8 \times 10^{-5} X^{2}$ & 83.5 \\
\hline- & $\begin{array}{l}\text { Total } \\
\text { number } \\
\text { lamina } \\
\text { of nodes }\end{array}$ & $\begin{array}{l}\text { Total } \\
\text { area }\left(\mathrm{cm}^{2}\right)\end{array}$ & $Y=100.0-27.0 X+4.5 X^{2}-0.033 X^{3}+7.6 \times 10^{-5} X^{4}$ & 90.7 \\
\hline 6 & $\begin{array}{l}\text { Total } \\
\text { number } \\
\text { of nodes }\end{array}$ & $\begin{array}{l}\text { Area of largest } \\
\text { lamina }\left(\mathrm{cm}^{2}\right)\end{array}$ & $Y=-23.0+8.0 X-0.049 X^{2}+8.1 \times 10^{-5} X^{3}$ & 81.0 \\
\hline
\end{tabular}

are not linearly related. Our data and analysis agree with hers. However, as noted earlier, the deviation from nonlinearity is small. The small difference of the

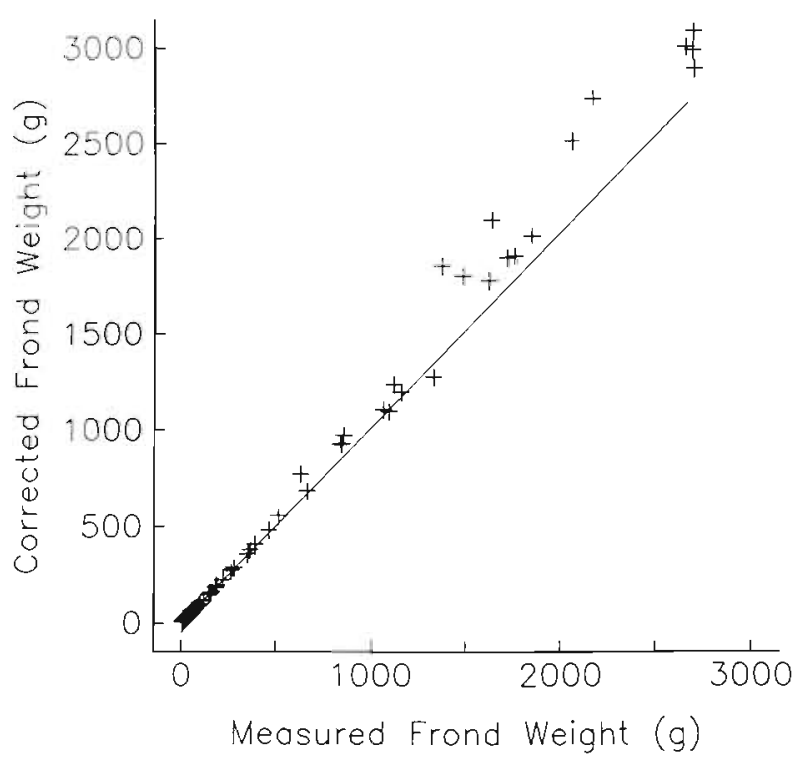

Fig. 14. Corrected frond biomass as a function of total frond biomass. Corrected biomass is an estimate of the frond biomass if there were no losses of blade tissue. It was calculated assuming that the basal 30 blades of fronds larger than 60 nodes had a fixed maximum size similar to that shown in Fig. 5. For blades closer to the apex, a blade was assumed to have lost tissue if it was less than $70 \%$ of the weight of the nearest whole blade in the apical direction. A new weight was calculated for blades with lost tissue by interpolating weights of nearest ' $w$ hole' blades on either side of it. The total corrected biomass is the sum of the whole blade weights, corrected blade weights, and total stipe weight density implies that area and mass are nearly equivalent measures of lamina tissue. Blade size on any given frond increased with increasing node number from either end, reaching a maximum near the 'center' when position is reckoned as node number. For blades near the apex, the increase toward the basal end was caused by increasing blade age and concomitant growth. For basal blades whose growth had stopped, this was not the case. Blades near the base could have been smaller because they were once large but had lost tissue (due to either senescence or grazing) or because they just never grew as large as blades closer to the apex. Both processes seem to be important (Fig. 5). The blades within about 30 nodes of the basal meristem at their largest size were smaller than the maximum size blades farther away and, therefore, never grew as large (Fig. 5). This was also noted by Clendenning (1971). In addition, blades from larger, presumably older, fronds were more variable in size, presumably because of tissue loss (Fig. 5). This pattern of smaller blades near the base and near the apex can be well described by our normalization techniques.

Frond morphology varies in complex ways with the total size of the frond. The technique of normalizing both the blade's node number and its size separates the effect of total frond size on a blade's dimensions from the effect of relative position on the frond. Combining 2 regression equations, one for the overall characteristics and another for the internal normalized characteristics, can yield a substantially better description of Macrocystis pyrifera morphology. For example, given the total length of a frond, the total number of nodes 
Table 4. Distribution of frond lengths within a plant

\begin{tabular}{|c|c|c|c|c|}
\hline Fig. & $\mathrm{x}$ & Y & Equation & $\begin{array}{c}\text { Variance } \\
\text { explained } \\
(\%)\end{array}$ \\
\hline 15 & $\begin{array}{l}\text { Frond } \\
\text { number }\end{array}$ & $\begin{array}{l}\text { Frond } \\
\text { length }(\mathrm{m})\end{array}$ & $Y=-0.30+0.51 X$ & 75.5 \\
\hline- & $\begin{array}{l}\text { Fractional } \\
\text { frond } \\
\text { number }\end{array}$ & $\begin{array}{l}\text { Fraction of } \\
\text { longest frond } \\
\text { length }\end{array}$ & $Y=0.016+0.50 X-1.0 X^{2}+4.5 X^{3}-3.0 X^{4}$ & 96.0 \\
\hline- & $\begin{array}{l}\text { Water } \\
\text { depth (m) }\end{array}$ & $\begin{array}{l}\text { Length of } \\
\text { longest } \\
\text { frond }(\mathrm{m})\end{array}$ & $Y=-0.79+1.4 X$ & 87.3 \\
\hline- & $\begin{array}{l}\text { Number of } \\
\text { stipes on } \\
\text { plant }\end{array}$ & $\begin{array}{l}\text { Length of } \\
\text { longest } \\
\text { frond }(\mathrm{m})\end{array}$ & $Y=5.1+0.39 X$ & 48.9 \\
\hline
\end{tabular}

can be estimated with good accuracy from a polynomial expression (Fig. 12). Any desired node number on the frond can be normalized by dividing by the total node estimate. Normalized distance from the apex is then calculated using the polynomial relationship between normalized distance and normalized node number. Normalized distance can then be converted to an absolute distance by multiplying by the previously specified total frond length.

This convoluted procedure improves the estimate of the distance to a given node over that obtained with a simple power series fit. Short fronds require fewer nodes to reach a given length than do long fronds (Fig. 10). A simple fit of accumulating length to node number which uses data for all the fronds did not account for this phenomenon. The simple fit explained $81 \%$ of the variance in distance as a function of node number. The procedure employing an estimate of total number of nodes and then the use of the normalized relationships explained $94 \%$ of the variance in distance as a function of node number. This method generated a new node position curve for each given frond length, a better model of biological reality than the simple fit, which generates 1 curve for all frond lengths.

The technique of using the cumulative blade area rather than the individual blade area as the variable to be fit in a regression is an effective way to smooth out the high variability in lamina area from blade to blade. There is a certain loss of degrees of freedom because of this smoothing. The cumulative blade area and the individual blade area can be related by calculating the derivative of the curve at the node or, equivalently, subtracting the cumulative area at the node from the cumulative area at the next node. Thus, the cumulative area relationships can be used for the same estimates as the individual lamina area estimates
Frond length distributions on Macrocystis pyrifera plants reflect the initiation rates and growth rates of the fronds. Several environmental factors (nutrition, light, temperature, and season) are thought to influcence these processes (Zimmerman 1983, Gerard 1976, 1983); it is surprising that a crude attempt to fit maximum frond length to a simple physical characteristic such as water depth explained a large (87\%) proportion of the sample variance. It is possible that environmental cues interact at the water surface to impose an ultimate limit on the length of surfaced fronds.

In this case, the combination of a dimensional overall fit (maximum length to number of stipes) with a dimensionless internal fit does not improve the prediction of frond length distributions [48.9\% $\times 96 \%$ $=46.9 \%$ ] compared to the simple dimensional fit (Fig. 15 ; variance explained $=76 \%$ ).

Any analysis of a data set as large as this emphasizes

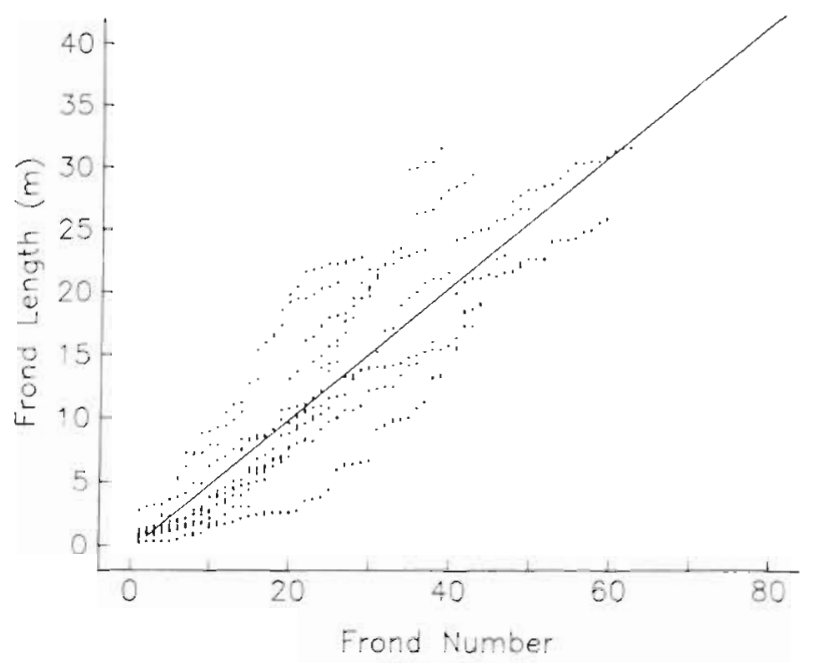

Fig. 15. Frond length as a function of frond number. Solid line is a 1 st-order fit to the data (Table 4) 
certain aspects of the data and neglects others. Kain (1982) made extensive use of logarithmic data transformations to describe Macrocystis pyrifera morphology. This manipulation weights small blades more heavily than large ones. For her purposes, which were to explore growth in the apical region, this bias was unimportant. However, the small blades near the apex constitute a small part of the total tissue mass. Small proportional variations in size of the large blades can be more significant in determining the distribution of total mass than variations in size of small laminae. This effect is lost in an logarithmic transformation of the data. The normalization which we used to describe kelp morphology has its own subtle bias. Because a large frond contains as many as 200 blades and because each blade has the same weight when the variance is calculated, a large frond counts more heavily than a small frond of 10 blades in determining the shape of our normalized curves.

While the techniques explained herein can be used to analyze data from other sites and for other species, the equations presented here are not necessarily valid for a useful description of Macrocystis plants at other sites. For example, our longest frond (26 m) weighed $3.6 \mathrm{~kg}$ and had $30000 \mathrm{~cm}^{2}$ of surface area. Coon (1981) found weights of $4 \mathrm{~kg}$ for a $15 \mathrm{~m}$ frond of $M$. augustifolia, almost twice the value for our fronds (Fig. 13). Wheeler (1978) presented data for a $12 \mathrm{~m}$ Macrocystis frond of similar length from off Santa Barbara which weighed $3.2 \mathrm{~kg}$ and had a total lamina area of 76370 $\mathrm{cm}^{2}$. Clendenning (1971) cited typical fronds with blade areas of $55360 \mathrm{~cm}^{2}$. However, the description of a range of frond sizes by normalizing by largest lamina, total number of nodes, and total length suggests the possibility that normalized areas, distance and node number relationships might be similar over wide areas. If this were so, then only whole frond relationships, such as total area or total number of nodes as a function of length, need be obtained at new sites. When combined with dimensionless internal fits, they would be sufficient to characterize local frond populations completely.

The curves fitted to different morphological properties of Macrocystis offer simple means of exploring the implications of changing kelp morphology. An example of this would be the calculation of lamina surface that a frond has below and at the water surface as a function of frond length. Such a value could be used to estimate the photosynthesis of a kelp frond if the light field were known and the relationship between area, light, and photosynthesis were available. To estimate the total area of the surface given the frond length $(\mathrm{L})$ and depth (D), we have used the relationship between length and total number of nodes ( $\mathrm{N}_{\text {; }}$ Table 3 ) to calculate $\mathrm{N}$. We then calculated the normalized length of tissue at the surface (l) as $1=(\mathrm{L}-\mathrm{d}) / \mathrm{L}$. Normalized node number (n) at l was calculated using a regression result (Table 2). The normalized accumulating area (a) was calculated using $\mathrm{n}$ and another regression relationship (Table 1). The total frond area (A) was calculated using the appropriate relationship with $N$. Finally, the lamina area at the surface $(a \times A)$ and that subsurface (A - a $\times$ A) were calculated (Fig. 16). Further possible uses of these regressions include cal-

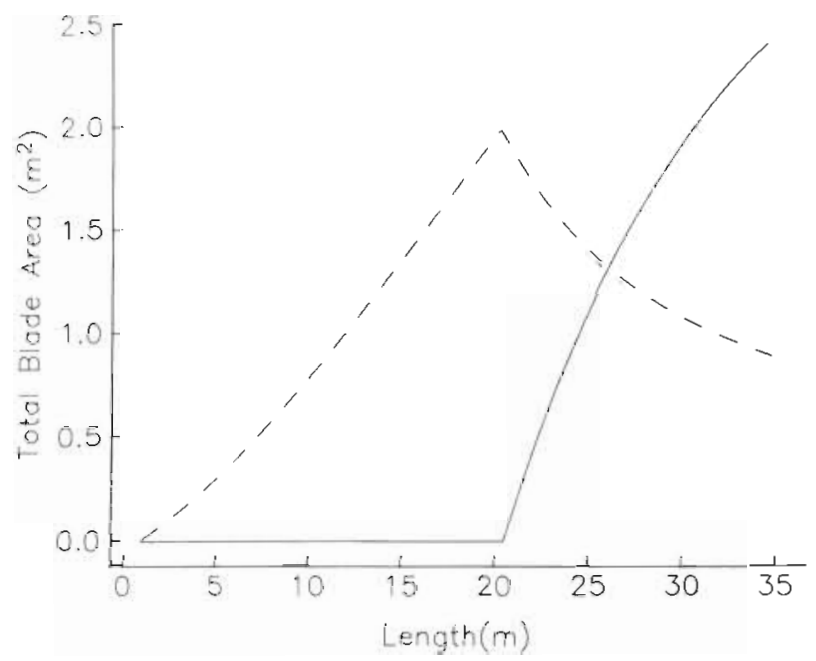

Fig. 16. Lamina area as a function of frond distance. Solid line $=$ total lamina area of a frond at the surface; dashed line $=$ total lamina area of a frond subsurface. Curves were calculated using regression relations for water $20 \mathrm{~m}$ deep. Subsurface area decreases once the frond reaches the surface. This is caused by the continual growth of stipe tissue which, as the frond grows, forces blades to the surface

culating more detailed distributions of lamina tissue in the water column, using this distributional data to make a model of light penetration through the water, and estimating how much tissue would be cut by harvesting at a given depth. We hope that others will also find these compact mathematical descriptions of $M$. pyrifera useful.

\section{CONCLUSION}

We developed a methodology for expressing patterns in frond morphology in terms of mathematical relationships. The availability of such relationships provides a new tool to facilitate a variety of investigations previously considered impossible because of difficulties coping with variability in frond morphology.

Acknowledgements. We thank E. Stewart for help and U. Heyman for many discussions. Dr. J. M. Jones provided helpful comments. Collection of the original data was funded by California Department of Fish and Game. Subsequent work was funded by the Gas Research Institute. 


\section{LITERATURE CITED}

Clendenning, K. A. (1971). Gross composition of kelp. In North, W. J. (ed.) The biology of giant kelp beds (Macrocystis) in California. Cramer, Lehre, FRG, p. 197-209

Coon, D. (1981). Studies of whole plant growth in Macrocystis augustifolia. Botanica Mar. 24: 19-27

Draper, N. R., Smith, H. (1966). Applied regression analysis. John Wiley, New York

Elias, C. O., Causton, D. R. (1976). Studies on data variability and the use of polynomials to describe plant growth. New Phytol. 77: 421 430

Gerard, V. A. (1976). Some aspects of material dynamics and energy flow in a kelp forest in Monterey Bay, California. $\mathrm{Ph}$. D. thesis, Univ. of California, Santa Cruz

Gerard, V. A. (1983). Factors affecting frond initiation rate. Annual Report for the Marine Biomass Program for 1982 W. M. Keck Eng. Lab., Calif. Inst. Technol.

Kain, J. M. (1982). Morphology and growth of the giant kelp Macrocystis pyrifera in New Zealand and California. Mar. Biol. 67: 143-157

Lobban, C. S. (1978a). The growth and death of the Macrocystis sporophyte (Phaephyceae, Laminaiales). Phycologia 17: $196-212$
Lobban, C. S. (1978b). Translocation of ${ }^{14} \mathrm{C}$ in Macrocystis pyrifera (giant kelp). Pl. Physiol., Lancaster 61: 585-589

North, W. J. (1971a). Introduction and background. In: North, W. J. (ed.) The biology of giant kelp beds (Macrocystis) in California. Cramer, Lehre, FRG, p. 1-97

North, W. J. (1971b). Growth of individual fronds. In: North, W. J. (ed.) The biology of giant kelp beds (Macrocystis) in California. Cramer, Lehre, FRG, p. 123-168

North, W. J. (1972). Observation on populations of Macrocystis. In: Abbott, I. A., Kurogi, M. (ed.) Contributions to the systematics of benthic marine algae of the north Pacific. Japanese Society of Phycology, Kobe, Japan, p. 75-92

Ricker, W. E. (1973). Linear regressions in fishery research. J. Fish. Res. Bd Can. 30: 409-434

Wheeler, W. N. (1978). Ecophysiological studies on the giant kelp. Macrocystis Ph. D. thesis, Univ, of California, Santa Barbara

Zimmerman, R. C. (1983). Seasonal patterns in the productivity of a giant kelp (Macrocystis pyrifera) forest: the effect of nutrient availability. Ph. D. thesis, Univ. of Southern California

This paper was presented by Professor T. S. Pearse; it was accepted for printing on July 31, 1985 